\title{
Anion Selective Electrode for High Performance Liquid Chromatography Detector Based on Oleophilic Anion-Exchange Resin Membrane
}

\author{
Sadayuki KoIzumI,* Toshihiko Imato** and Nobuhiko IshibaSHI ${ }^{* *}$ \\ *Department of Industrial Chemistry, Fukui College of Technology, Sabae 916 \\ **Department of Applied Analytical Chemisty, Faculty of Engineering, Kyushu University, \\ Hakozaki Fukuoka 812
}

\begin{abstract}
A system is described for the separate determination of anions using HPLC with a potentiometric detector based on an ion selective electrode (ISE). The ISE consists of an oleophilic anion-exchange resin membrane impregnated with an organic solvent. A sodium sulfate solution containing a trace level of a primary ion for the electrode was used as an eluent. Sensitivity and selectivity of the ISE detector varies with a solvent species imbibed in the detector membrane and an ionic form of the membrane. Chromatograms for oxyacid anions $\left(\mathrm{IO}_{3}{ }^{-}\right.$, $\mathrm{BrO}_{3}^{-}, \mathrm{ClO}_{3}^{-}$and $\mathrm{NO}_{3}^{-}$) are shown, and relationships between chromatographic sensitivity and selectivity coefficients of the ISE detector are discussed.
\end{abstract}

Keywords Anion selective electrode, liquid chromatography, liquid membrane electrode, selectivity coefficient

In recent years, several papers have been published on the use of ion selective electrodes (ISEs) for a detector in ion chromatography. ${ }^{1-11}$ One of advantages of ion selective electrode detector in ion chromatography is that no suppressor column is necessary, if electrolytes of eluent are insensitive to the electrode membrane. The ISEs employed so far were both of solid membrane types $^{1-8}$, and liquid membrane type ${ }^{10}$ or solvent polymeric membrane types. $4,9,11$ The latter two membranes contain mobile ion-exchanger sites. These kinds of membrane electrodes may be generally short in their lives, due to the leak of an ion-exchange site and other membrane components from the membranes to eluent solutions, though these electrodes are capable to detect much more kinds of anions, compared with solid membrane electrodes.

In previous papers ${ }^{12-14}$, we have developed the anion selective electrode based on the oleophilic ion-exchange resin membrane. This membrane is expected to have a long life, since its ion-exchange site is fixed to the resin matrix. In addition, it may have the same advantage as solvent polymeric membranes or liquid membranes, i.e., we can utilize the various selectivity among anions, depending on the organic solvent species contained in the membrane.

In the present paper, we firstly determine selectivities of several electrodes with a pure liquid membrane in order to determine selectivities of the oleophilic resin membrane impregnated with an organic solvent. Next, we estimate performances of the oleophilic membrane electrode for a detector in flow injection analysis and HPLC. In a HPLC system, anions separated with the anion exchange column are quantified with the detector. We discuss relationships between peak heights in chromatograms and the solvent species imbibed in the resin membrane as well as the anionic form of the membrane.

\section{Experimental}

\section{Reagents}

Nitrobenzene, $o$-dichlorobenzene, $o$-nitrophenyl-octyl-ether(o-NPOE), tributyl phosphate(TBP) and decan1-ol were used as solvents composing liquid membranes as well as solvents to be imbibed into the oleophilic resin membrane. $o$-NPOE was synthesized according to the method by Allen et al. ${ }^{16}$ and purified by distillation. Other solvents of analytical reagent grades were used as received without further purification. Organic solutions for liquid ion-exchanger membranes were prepared by dissolving trioctylmethylammonium chloride (Capriquate; Dojin Co., Japan) into abovementioned solvents. Other chemicals used were of analytical reagent grades.

Estimation of selectivity coefficients of liquid membrane electrodes

Selectivities of liquid membranes were evaluated by the separate solution method. ${ }^{15}$ The electromotive 
force of the following membrane cell was measured with an Orion Ionalyzer 801 A.

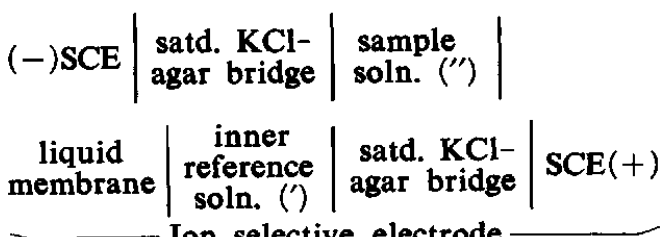

The inner reference solution(') was $0.1 \mathrm{M}$ sodium chloride solution and the sample(") was $1 \times 10^{-1} \mathrm{M}$ to $1 \times 10^{-3} \mathrm{M}$ sodium or potassium salt of a monovalent anion, such as iodate, bromide, nitrate, chlorate or thiocyanate ion. The liquid membrane was an organic solvent solution of $1 \times 10^{-4} \mathrm{M}$ trioctylmethylammonium chloride. Figure 1 schematically shows the membrane systems. For the membrane solvents heavier than water, the glass cell (a) was used, and for lighter solvents, the glass cell (b) was used. The cell (1) corresponds to a chloride sensitive electrode, since the liquid membrane consists of the organic solution of trioctylmethylammonium chloride. Stable membrane potentials were observed within about thirty seconds after setting up the cell.

\section{Ion-exchange resin membrane}

The oleophilic anion-exchange resin membrane was prepared according to the previous paper. ${ }^{14}$ The membrane possesses a fixed benzyltrioctylammonium ion as an anion-exchange site. The resin membrane

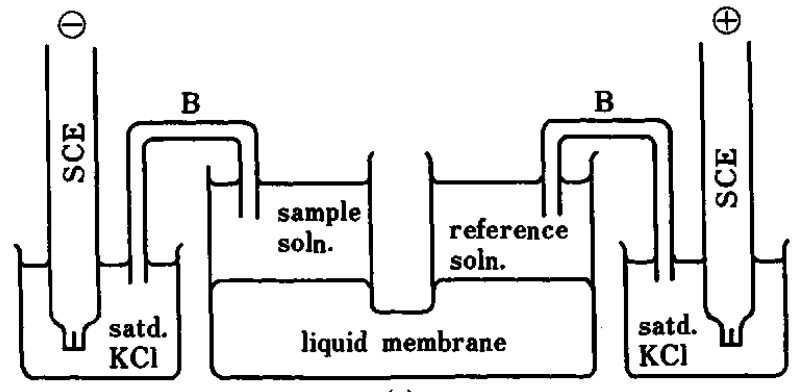

(a)

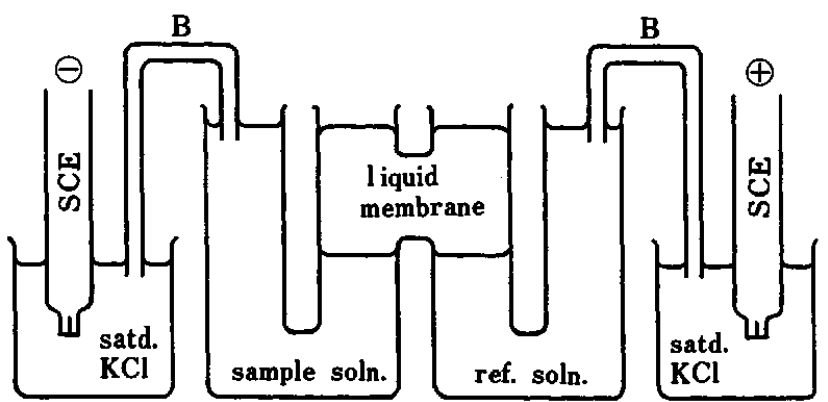

(b)

Fig. 1 Experimental cells. Configuration (a) was used for the system of liquid membrane solvents heavier than water, and (b) for the system of liquid membrane solvents lighter than water. $\mathrm{B}, 3 \mathrm{M} \mathrm{KCl}$ salt bridge. impregnated with a water-immiscible organic solvent shows the same orders of potentiometric selectivities and sensitivities as the corresponding liquid anion selective membrane. ${ }^{12}$

The resin membrane was usually stocked in ethanol in the chloride form, which were converted into the nitrate or perchlorate form by repeated immersion into a portion of a new ethanol solution of sodium nitrate or sodium perchlorate. ${ }^{12}$ Before the membrane is used, the imbibed alcohol in the membrane was replaced to an other solvent, such as $o-\mathrm{NPOE}$, TBP or decan-1-ol, by the repeated immersion in an aliquot of the corresponding solvent.

\section{Ion selective electrode detector}

A cross section of the detector cell used in flow injection analysis and HPLC is shown in Fig. 2. The cell body made of polytrifluoroethylene was furnished from Denki Kagaku Keiki Co. (Musashino, Japan). The membrane impregnated with an organic solvent was fitted to the bottom of the ion selective electrode body, and the same organic solvent was filled into the solvent reservoir of the body in order to replenish the solvent leaked into the sample solution. The cell volume of the flow through detector is about $10 \mu$ l. The potential of the ion selective electrode against an reference electrode was measured with an Ion-Meter (Denki Kagaku Keiki Co., IOC-10) and the chromatograms were drawn on a recorder (Watanabe Instruments Co., SR6521). The electrical signal from the detector was transmitted through an A-D converter (Shimadzu Co., RS232C) to a computer (Nippon Electric Co., 9801) (see Fig. 3), and was converted to the value proportional to the concentration of the sample anion from its logarithmic value.
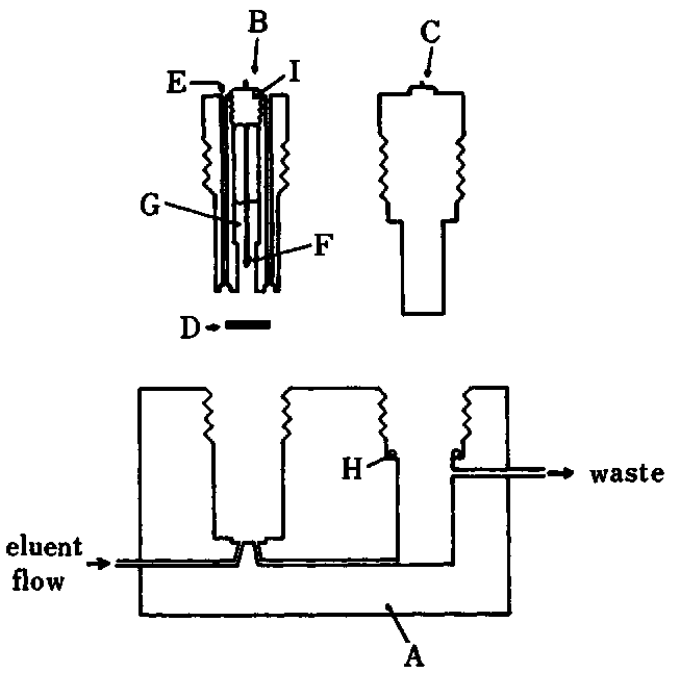

Fig. 2 The ion selective electrode detector: A, cell body; B, ion selective electrode (ISE); C, reference electrode (SCE); D, anion exchange resin membrane; E, solvent reservoir; $F$, silver-silver chloride electrode; $G$, inner solution $\left(1 \times 10^{-2} \mathrm{M} \mathrm{NaCl}+1 \times 10^{-2} \mathrm{M}\right.$ sodium salt of primary anion); $\mathrm{H}$, O-ring; I, inner electrode. 


\section{Flow injection analysis and HPLC system}

Performance of the membrane detector was analyzed by flow injection technique, using the system of Fig. 3, from which the separation column was removed. The inner reference solution of the detector electrode was a mixed solution of sodium chloride and sodium salt of an anion primary to an electrode. The concentration of the both sodium salts is $1.0 \times 10^{-2} \mathrm{M}$. A carrier solution was $1 \times 10^{-3} \mathrm{M}$ sodium sulfate containing a sodium salt of a primary anion at $1.0 \times 10^{-5} \mathrm{M}$. A function of a primary anion is to stabilize the base line potential. A sample solution $(1.6 \mathrm{ml})$ was injected into the carrier solution. Before injection, the solution

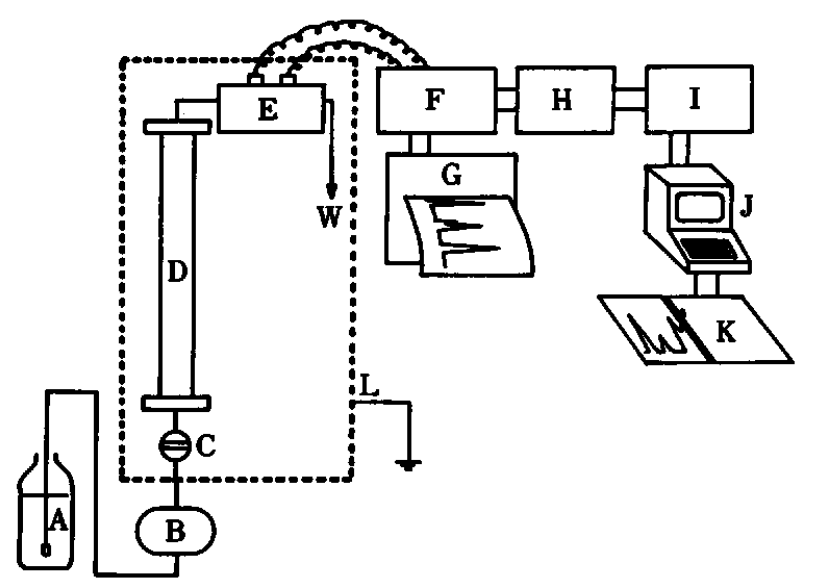

Fig. 3 Schematic diagram of chromatographic system: A, eluent or carrier solution; B, pump (Yanagimoto Co., L4000 W); C, sample injector (Gasukuro Kogyo Co., MPV-6 or Rheodyne Co., 7125); D, anion-exchange column (Zipax SAX, i.d. $4 \mathrm{~mm} \times 300 \mathrm{~mm}$ ); E, detector (in Fig. 1); F, potentiometer (Denki Kagaku Keiki Co., IOC-10); G, recorder (Watanabe Instruments Co., SR5621); H, equipment for transmission of data (Shimadzu Co., Chromato PAC); I, A-D converter (Shimadzu Co., RS232C); J, computer (Nippon Electric Co., 9801); K, X-Y plotter (Watanabe Instrument Co., MP 1000-21); L, shield box; W, waste. consisting of sodium sulfate and sodium salt of the stabilizer anion was added to the sample solution to be the same ionic background as the carrier solution. The electrode potential was measured inside an electric shield box to minimize electrostatic disturbance from the outside (see Fig. 3).

For HPLC analysis, an anion exchanger resin Zipax SAX column (i.d. $4 \mathrm{~mm} \times 300 \mathrm{~mm}$ ) was used for separation of mixed anions. The carrier solution in the flow injection analysis was used as an eluent in HPLC system. The sample solution $(200 \mu \mathrm{l})$ was injected by means of an injector (Rheodyne, Co., 7125). The other conditions were the same as those used in the flow injection system.

\section{Results and Discussion}

\section{Response of the liquid membrane electrode}

The electrode potential of the chloride ion selective liquid membrane electrode constructed as the cell (1) is assumed to obey the following Nicolsky equation against the reference electrode.

$$
E=\text { const. }-S \ln \left[\left(a_{\mathrm{Cl}}^{\prime \prime}+k_{\mathrm{Cl}, \mathrm{j}}^{\mathrm{pot}} a_{\mathrm{j}}^{\prime \prime}\right) / a_{\mathrm{Cl}}^{\prime}\right]
$$

where $a_{c 1}^{\prime \prime}$ and $a_{j}^{\prime \prime}$ are activities of the chloride ion and a coexisting foreign ion $\mathrm{j}$ in a sample solution, and $a_{\mathrm{Cl}}^{\prime}$ is an activity of the chloride ion in an inner reference solution. A notation of $k_{\mathrm{C}, \mathrm{j}}^{\mathrm{pot}}$ is a potentiometric selectivity coefficient of an ion $\mathrm{j}$ over the chloride ion. For the $0.1 \mathrm{M}$ chloride ion solution as the inner reference solution, an ideal Nernstian slope value was obtained for sample solutions from $1.0 \times 10^{-1} \mathrm{M}$ to $1.0 \times 10^{-3} \mathrm{M}$. When a sample solution contains a different $\mathrm{j}$ from $\mathrm{Cl}^{-}$as an anion, that is, when $a_{\mathrm{Cl}}^{\prime \prime}=0$, Eq. (2) can be reduced to the following equation.

$$
E=\text { const. }-S \ln \left(k_{\mathrm{Cl}, \mathrm{j}}^{\text {pot }} a_{\mathrm{j}}^{\prime \prime} / a_{\mathrm{Cl}}^{\prime}\right)
$$

From Eq. (3), plots of $E$ against $\log a_{j}^{\prime \prime}$ may be expected to be on a straight line with the Nernstian slope under

\begin{tabular}{|c|c|c|c|c|c|c|c|}
\hline \multirow[b]{2}{*}{ Ion $\mathrm{j}$} & \multicolumn{7}{|c|}{ Membrane solvent } \\
\hline & $\begin{array}{l}\text { o-Dichloro- } \\
\text { benzene }\end{array}$ & $\begin{array}{l}\text { o-Nitrophenyl- } \\
\text { octylether }\end{array}$ & $\begin{array}{c}\text { Nitro- } \\
\text { benzene }\end{array}$ & $\begin{array}{l}\text { 1,2-Dichloro- } \\
\text { ethane }^{\mathfrak{a}}\end{array}$ & $\begin{array}{c}\text { Tributyl } \\
\text { phosphate }\end{array}$ & Chloroform ${ }^{\mathrm{a}}$ & Decan-1-ol \\
\hline $\mathrm{IO}_{3}^{-}$ & $7.4 \times 10^{-3}$ & $1.5 \times 10^{-2}$ & $1.1 \times 10^{-2}$ & - & $4.0 \times 10^{-2}$ & - & $8.1 \times 10^{-2}$ \\
\hline $\mathrm{BrO}_{3}^{-}$ & $1.7 \times 10$ & $1.1 \times 10$ & 9.9 & - & 3.1 & 一 & $5.2 \times 10^{-1}$ \\
\hline $\mathrm{Br}^{-}$ & $4.5 \times 10$ & $3.5 \times 10$ & $3.2 \times 10$ & $2.2 \times 10$ & 8.1 & $2.3 \times 10$ & $2.7^{a}$ \\
\hline $\mathrm{NO}_{3}{ }^{-}$ & $3.8 \times 10^{2}$ & $2.7 \times 10^{2}$ & $3.1 \times 10^{2}$ & $1.4 \times 10^{2}$ & $3.4 \times 10$ & $2.5 \times 10$ & $3.4^{\mathrm{a}}$ \\
\hline $\mathrm{ClO}_{3}^{-}$ & $9.0 \times 10^{2}$ & $5.7 \times 10^{2}$ & $5.6 \times 10^{2}$ & $2.8 \times 10^{2}$ & $6.6 \times 10$ & $4.5 \times 10$ & $3.2^{\mathrm{a}}$ \\
\hline $\mathrm{I}^{-}$ & - & - & $7.1 \times 10^{3}$ & $3.2 \times 10^{3}$ & - & $1.2 \times 10^{3}$ & $1.4 \times 10^{1} \mathrm{a}$ \\
\hline $\mathrm{SCN}^{-}$ & $2.9 \times 10^{4}$ & - & $1.5 \times 10^{4}$ & $6.8 \times 10^{3}$ & - & $7.8 \times 10^{2}$ & $4.1 \times 10^{1}$ \\
\hline $\mathrm{BF}_{4}^{-}$ & - & - & $4.4 \times 10^{4}$ & $1.4 \times 10^{4}$ & - & $1.5 \times 10^{2}$ & $2.6^{\mathrm{a}}$ \\
\hline $\mathrm{ClO}_{4}^{-}$ & $6.4 \times 10^{5}$ & $4.5 \times 10^{5}$ & $4.6 \times 10^{s}$ & $1.5 \times 10^{5}$ & $2.8 \times 10^{4}$ & $2.5 \times 10^{3}$ & $2.0 \times 10^{1}=$ \\
\hline
\end{tabular}

Table 1 Selectivity coefficients $\left(k_{\mathrm{Cl}, \mathrm{j}}^{\text {pot }}\right)$ of chloride ion selective liquid membrane electrodes

a. Taken from Ref. 15. 
a constant value of $a_{\mathrm{Cl}}^{\prime}$. The observed potential-activity plots for the various sample anions showed theoretical slopes. Selectivity coefficients were evaluated by using the observed potentials for $0.1 \mathrm{M}$ anions $\mathrm{j}$ against the potential for $0.1 \mathrm{M}$ chloride solution and the observed $S$ values according to equation (3). We used the values of concentrations instead of activities for the calculation of selectivity coefficients.

Selectivity of the chloride ion-sensitive electrodes for various anions $\mathrm{j}$ is listed in Table 1 . The $k_{\mathrm{Cl} j \mathrm{j}}^{\mathrm{pot}}$ values obtained by Jyo et al. ${ }^{\text {15 }}$ were also listed in the same Table. Jyo et al. had used the Crystal Violet cation or the methyltrioctylammonium ion as an anion-exchanger site. However, the selectivity of the liquid membrane electrode is independent of a kind of an ion exchanger site, if there are no special interactions between an ion exchange site and an counter ion. ${ }^{22}$ In order to take a bird-eye view of the solvent effect, the selectivity diagram for the liquid anion-exchange membranes is shown in Fig. 4. The selectivity sequence of anions is generally consistent with the Hofmeister series for membranes of $o$-dichlorobenzene, $o$-NPOE, nitrobenzene, 1,2-dichloroethane (DEC) and TBP. However, chloroform and decan-1-ol membranes show partially different anion selectivities from other solvent membranes. Relatively high selectivities for halide ions are observed on the chloroform membrane. The decan-1-ol membrane shows low selectivities between various anions, compared with the other membranes, but the selecting for thiocyanate ion is relatively high.

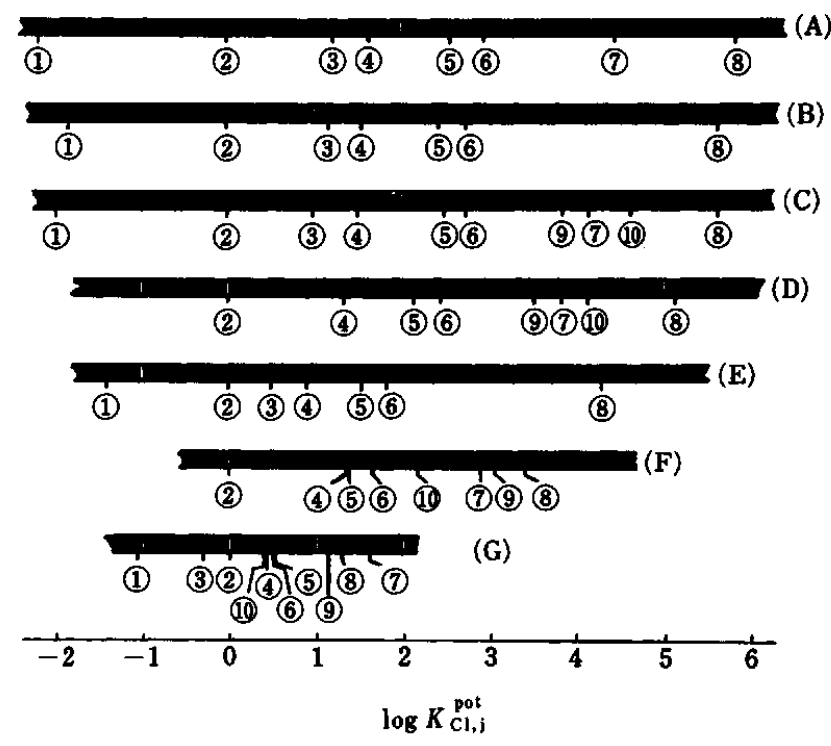

Fig. 4 Selectivity diagram for liquid anion exchanger membrane (reference, $\mathrm{Cl}^{-}$). Membrane solvent: (A) o-dichlorobenzene, (B) $o$-nitrophenyl octyl ether, (C) nitrobenzene, (D) 1,2-dichloroethane, (E) tributyl phosphate, (F) chloroform, (G) decan-1-ol. (1) $\mathrm{IO}_{3}^{-}$, (2) $\mathrm{Cl}^{-}$, (3) $\mathrm{BrO}_{3}^{-}$, (4) $\mathrm{Br}, \mathrm{C}^{-} \mathrm{NO}_{3}^{-}$, (6) $\mathrm{ClO}_{3}^{-}$, (7) $\mathrm{SCN}^{-}$, (OClO $_{4}^{-},\left(9 \mathrm{I}^{-}\right.$, (1) $\mathrm{BF}_{4}^{-}$.

\section{Potential response in flow injection system}

When the carrier solution flows through the ISE detector of the FIA system described in the experimental section, a potential of the detector with the chloride form membrane is shown by Eq. (4).

$$
E=\text { const. }-S \ln \left[\left(a_{\mathrm{Cl}}^{\prime \prime}+k_{\mathrm{Cl}_{1}, \mathrm{SO}_{4}{ }^{2-}}^{\mathrm{pot}^{\prime \prime}}\left(a_{\mathrm{SO}_{2}{ }^{2}}^{\prime \prime}\right)^{1 / 2}\right) / a_{\mathrm{Cl}}^{\prime}\right] \cdots
$$

where $a_{C 1}^{\prime \prime}$ and $a_{S_{0} 2^{2-}}$ are activities of the chloride and sulfate ions in a carrier solution, respectively. $a_{c 1}^{\prime}$ is for the chloride ions in an inner reference solution of the detector. As the sulfate ion can be assumed to be insensitive to the electrode, Eq. (4) is reduced to Eq. (5).

$$
E=\text { const. }-S \ln \left(a_{\mathrm{Cl}}^{\prime \prime} / a_{\mathrm{Cl}}^{\prime}\right)
$$

This $E$ value corresponds to a base line potential in the flow system. When a sample of an univalent ion $j$ injected into the carrier solution arrives at the detector, the potential is expressed by Eq. (6), and the potential difference $E$ is shown by Eq. (7).

$$
\begin{aligned}
& E=\text { const. }-S \ln \left[\left(a_{\mathrm{Cl}}^{\prime \prime}+k_{\mathrm{Cl}, j}^{\mathrm{pot}} a_{j}^{\prime \prime}\right) / a_{\mathrm{Cl}}^{\prime}\right] \\
& \Delta E=-S \ln \left[1+\left(k_{\mathrm{Cl}, j}^{\mathrm{pot}} a_{j}^{\prime \prime}\right) / a_{\mathrm{Cl}}^{\prime \prime}\right]
\end{aligned}
$$

As $a_{C i}^{\prime \prime}$ is constant, $\Delta E$ is dependent on $\ln k_{C l_{j}}^{p o a} a_{j}^{\prime \prime}$

Figure 5 illustrates response peaks obtained with the chloride ion selective electrode with the membrane impregnated with $o$-NPOE or decan-1-ol to sample anions. A relatively large volume of samples for the cell volume of the detector was injected into the carrier solution. Therefore, a central part of a segment of an injected sample is expected to reach to the electrode detector without any dilution with the carrier solution. Presence of plateaus in the recordered peaks in Fig. 5 is considered to reflect this situation. The calibration curves for various $j$ ions and chloride ions by the chloride ion selective membrane electrodes are shown
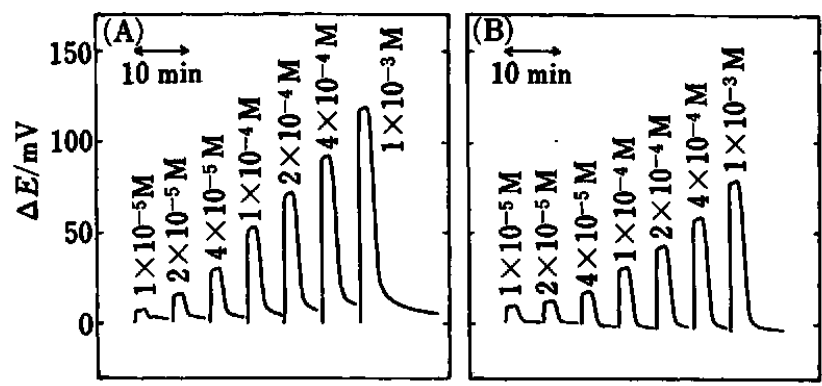

Fig. 5 FIA peaks of $\mathrm{BrO}_{3}^{-}$by using the chloride ion selective electrode based on an oleophilic anion exchange resin membrane impregnated with (A) o-NPOE and (B) decan1-ol. Carrier solution, $1 \times 10^{-3} \mathrm{M} \mathrm{Na} 2 \mathrm{SO}_{4}-1 \times 10^{-5} \mathrm{M} \mathrm{NaCl}$ mixed solution; flow rate, $1.0 \mathrm{ml} / \mathrm{min}$; injected volume of sample, $1.6 \mathrm{ml}$; mixed sample solution, $\left(1 \times 10^{-5}-1 \times 10^{-3} \mathrm{M}\right)$ $\mathrm{BrO}_{3}^{--} 1 \times 10^{-3} \mathrm{M} \mathrm{Na}_{2} \mathrm{SO}_{4}-1 \times 10^{-5} \mathrm{M} \mathrm{NaCl}$ 
in Fig. 6. In the case of the flow cell detector with the $o$-NPOE-imbibed oleophilic resin membrane, the calibration curves for the chlorate, nitrate, bromate, chloride and iodate ion are shown in (A) of Fig. 6. For tributyl phosphate or decan-1-ol imbibed membranes, the curves are shown by (B) or (C) of Fig. 6, respectively. For the high concentration of the sample anion, the calibration curves are almost linear with nearly Nernstian slopes, since $a_{\mathrm{Cl}}^{\|}\left(1 \times 10^{-5} \mathrm{M}\right)$ is negligibly small compared with the term $k_{\mathrm{Cl}, \mathrm{j}}^{\mathrm{pot}} a_{\mathrm{j}}^{\prime \prime}$ in Eq. (6). From (A) in Fig. 6, it is found that the sensitivities are different among anions. In the case of the $o$-NPOE imbibed membrane, $1.0 \times 10^{-6} \mathrm{M}$ chlorate or nitrate can be detected, whereas it is not easy to determine $1.0 \times$ $10^{-3} \mathrm{M}$ iodate. But in the case of the tributyl phosphate membrane, as shown in (B) of Fig. 6, the sensitivity for the detection of chlorate or nitrate ion is low and its limit is almost $1.0 \times 10^{-5} \mathrm{M}$. In the case of decan-1-ol membrane, $(C)$, the difference of sensitivities among these anions is further small.
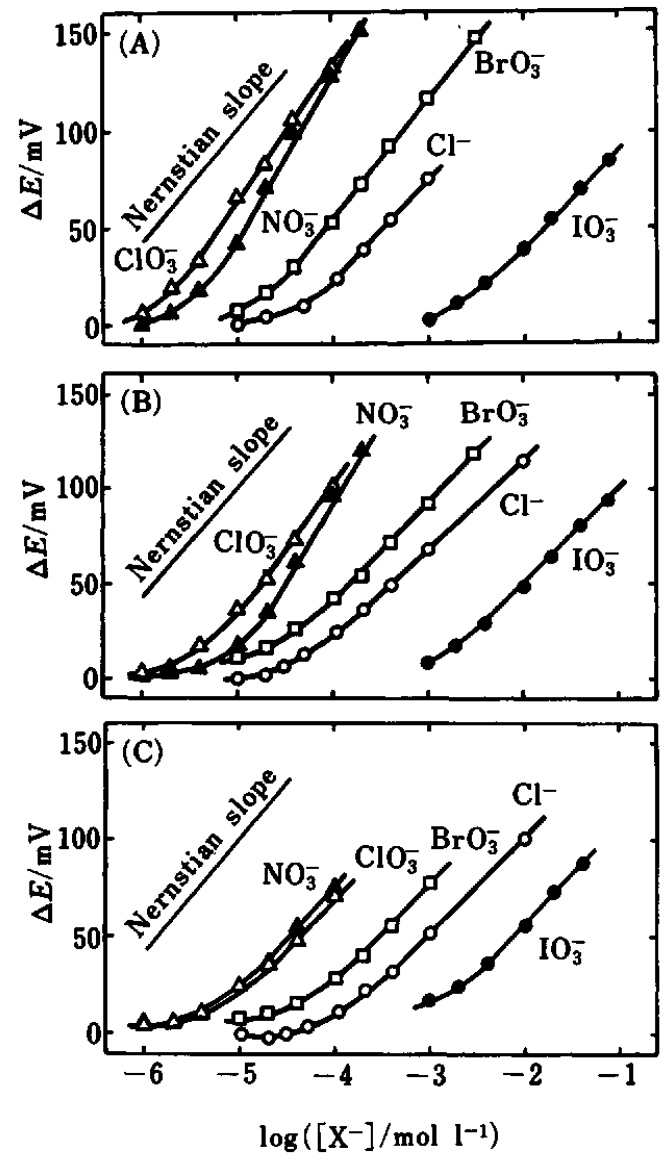

Fig. 6 Calibration curves for the oxyacid anions by using the chloride ion selective electrode based on the oleophilic anion exchange resin membrane impregnated with an organic solvent. Solvent impregnated, (A) $o$ nitrophenyloctylether; (B) tributyl phosphate; (C) decan-1-ol.
Effects of solvent species and ionic forms of resin membranes on chromatographic peak

When the ISE detector with the membrane of the chloride ion form is used for a HPLC detector, the base line potential and the potential response for a sample ion $\mathrm{j}$ eluted from the separation column of the chromatograph are expressed by Eq. (5) and Eq. (6), respectively. Accordingly, a peak height in the chromatogram, $E_{\text {peak }}$, that is, the potential change from the base line will be expressed by the following equation,

$$
E_{\text {peak }}=2.303 S \log \left[1+k_{\mathrm{Cl}, \mathrm{j}}^{\mathrm{pot}}\left(a_{\mathrm{j}}^{\prime \prime \max } / a_{\mathrm{Cl}}^{\prime \prime}\right)\right] \ldots \ldots
$$

where $a_{j}^{\prime \prime m a x}$ is an activity of a sample $j$ at a maximum peak height. Eq. (9) is generally rewritten to Eq. (10).

$$
E_{\text {peak }}=2.303 S \log \left[1+k_{i, j}^{\text {pot }}\left(a_{j}^{\prime \prime \max } / a_{i}^{\prime \prime}\right)\right]
$$

Figure 7 shows typical ion chromatograms obtained by detectors with the ion-exchange membrane in the $\mathrm{Cl}^{-}, \mathrm{NO}_{3}^{-}$or $\mathrm{ClO}_{4}^{-}$ion forms, respectively. The sample solution is a mixture of oxyacid anions $\left(\mathrm{IO}_{3}^{-}, \mathrm{BrO}_{3}^{-}\right.$, $\mathrm{ClO}_{3}^{-}$and $\mathrm{NO}_{3}^{-}$). Concentrations are $1 \times 10^{-2} \mathrm{M}$ for $\mathrm{IO}_{3}^{-}$and $1 \times 10^{-4} \mathrm{M}$ for the other three anions. The $1.0 \times 10^{-3} \mathrm{M}$ sodium sulfate solution was suitable as an eluent for separation of sample anions through the ionexchange column.

Sodium salts of phosphate, carbonate and acetate

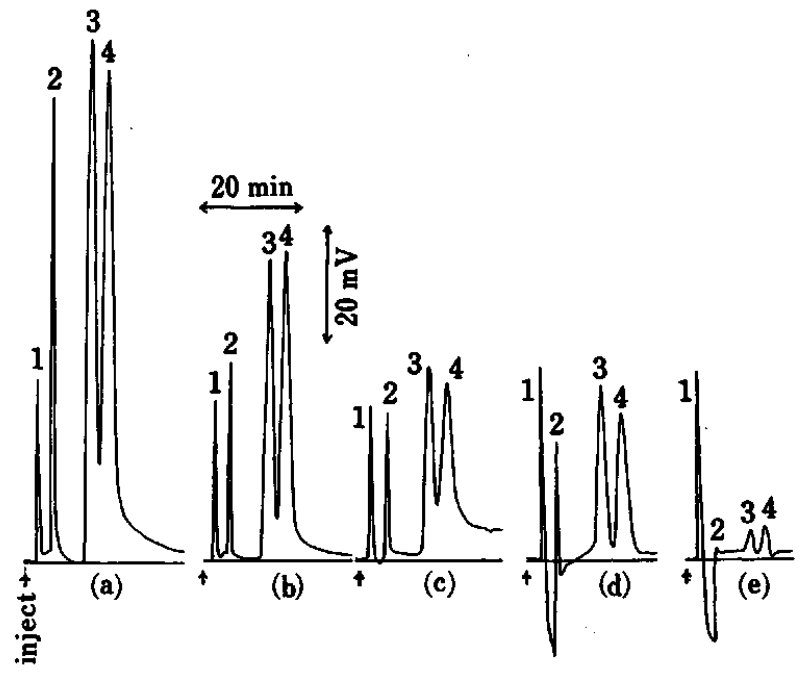

Fig. 7 Chromatograms for oxyacid anions by oleophilic resin membrane ion selective detectors. Detector: (a), (b) and (c), $\mathrm{Cl}^{-}$ISE; (d), $\mathrm{NO}_{3}^{-} \mathrm{ISE}$; (e), $\mathrm{ClO}_{4}^{-}$ISE. Imbibed solvent to the membrane: (a), (d) and (e), o-NPOE; (b), TBP; (c), decan-1-ol. Eluent: (a), (b) and (c), $1 \times 10^{-3} \mathrm{M}$ $\mathrm{Na}_{2} \mathrm{SO}_{4}-1 \times 10^{-5} \mathrm{M} \mathrm{NaCl}$; (d), $1 \times 10^{-3} \mathrm{M} \mathrm{Na}_{2} \mathrm{SO}_{4}-1 \times 10^{-5} \mathrm{M}$ $\mathrm{NaNO}_{3}$; (e), $1 \times 10^{-3} \mathrm{M} \mathrm{Na} \mathrm{SO}_{4}$. Sample, $1 \times 10^{-2} \mathrm{M} \mathrm{IO}_{3}^{--}$ $1 \times 10^{-4} \mathrm{M} \mathrm{BrO}_{3}^{--} 1 \times 10^{-4} \mathrm{M} \mathrm{NO}_{3}^{--} 1 \times 10^{-4} \mathrm{M} \mathrm{ClO}_{3}^{-}$mixed solution; injected volume, $200 \mu \mathrm{l}$; column, Zipax SAX (i.d. $4 \mathrm{~mm} \times 300 \mathrm{~mm}$ ); flow rate, $1.0 \mathrm{ml} / \mathrm{min}$. Peak: 1 , $1 O_{3}$; 2, $\mathrm{BrO}_{3}^{-} ; 3, \mathrm{NO}_{3}^{-} ; 4, \mathrm{ClO}_{3}^{-}$. 
were unsuitable as an eluent, since the phosphate salt solution has too strong eluting power to separate these oxyacid anions and the peaks of the anions overlap each other. The eluting powers of sodium carbonate and acetate are weak.

The effect of solvent species imbibed in the resin membrane on the chromatogram can be observed in (a), (b) and (c) in Fig. 7. The peak heights are high in the order of $0-\mathrm{NP} \cap E>\mathrm{TBP}>$ decan-1-ol. This can be explained based on the $k_{\mathrm{Cl}, \mathrm{j}}^{\mathrm{pot}}$ values shown in Table 1. Values of $k_{\mathrm{Cl}, \mathrm{NO}_{3}}^{\text {pot }}$ for $o$-NPOE, TBP and decan-1-ol based membranes are $2.7 \times 10^{2}, 34$ and 3.4 , respectively. When a solvent such as $o$-NPOE, which shows large selectivity differences between various ions, is imbibed, anions are sensitively detected as shown in Fig. 7.

The effect of the ionic form of the resin membrane on sensitivity in chromatograms can be observed by (a), (d) and (e) of Fig. 7. Sensitivity is in the order of $\mathrm{Cl}^{-}$form $>\mathrm{NO}_{3}{ }^{-}$from $>\mathrm{ClO}_{4}^{-}$form, that is, the electrode with a membrane containing a less selective ion as an counter ion gives higher sensitivity, being coincidence with expectation from Eq. (10). For

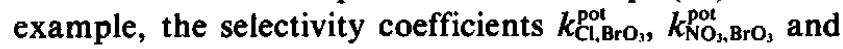
$k_{\mathrm{ClO}_{10}, \mathrm{BrO}}^{\mathrm{pot}}$ for the $o$-NPOE-based membrane electrode are $11,4.2 \times 10^{-3}$ and $2.5 \times 10^{-5}$, respectively, and these selectivity coefficients are reflected on the peak heights for $\mathrm{BrO}_{3}^{-}$in Fig. 7.

When the perchlorate form resin membrane was used, the perchlorate ion was not added to the eluent as the potential stabilizer. Since the perchlorate ion has a high affinity to the resin, compared with the other ions, it is difficult to elute the perchlorate ion from the separation column. The perchlorate ion, if necessary, should be added to an eluent by means of the postcolumn method.

The negative peaks appearing in the rear place of the $\mathrm{IO}_{3}{ }^{-}$peak in the chromatogram (d) and (e) of Fig. 7, can be qualitatively explained as follow. A sample ion $\mathrm{j}\left(\mathrm{IO}_{3}^{-}\right)$brought at the membrane surface by a carrier is exchanged with the primary ion $\mathrm{i}\left(\mathrm{NO}_{3}{ }^{-}\right.$or $\left.\mathrm{ClO}_{4}{ }^{-}\right)$in the membrane, like Eq. (11).

$$
\mathrm{i} \text { (membrane })+\mathrm{j} \text { (soln.) } \longrightarrow \mathrm{j} \text { (membrane })+\mathrm{i}(\text { soln. })
$$

After a band of an ion $\mathrm{j}$ passed away the detector, the exchange reaction proceeds toward the reverse direction to an arrow shown in Eq. (11) and results in the lowering of concentration of a stabilizer ion $i$ in an eluent. This lowering due to the reverse reaction may give rise to the negative peak in the chromatogram.

The potential lowering will be theoretically treated in elsewhere. ${ }^{1}$

\section{Calibration of peak heights in chromatograms}

In the case of the nitrate ion selective electrode with the membrane impregnated with $o-N P O E$, the peak heights on the chromatograms are shown in Fig. 8. The signals are converted to the values proportional to

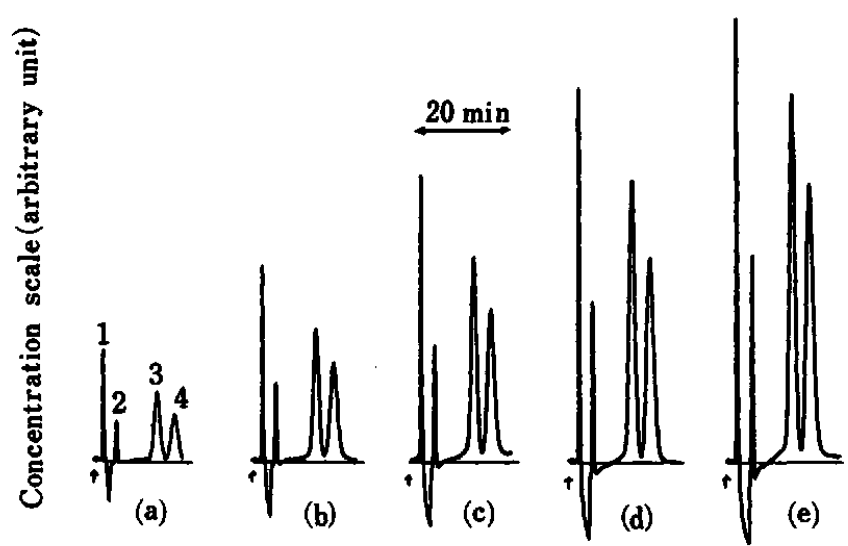

Fig. 8 Chromatographic peaks of oxyanions represented with nitrate ion selective electrode based on an oleophilic anion-exchange resin membrane impregnated with $o$-NPOE. Peak heights are represented in concentration unit. Injected. sample volume, $200 \mu \mathrm{l}$; sample, mixed solution of $\mathrm{IO}_{3}^{-}, \mathrm{BrO}_{3}^{-}, \mathrm{NO}_{3}^{-}$and $\mathrm{ClO}_{3}^{-}$. (a) $\mathrm{IO}_{3}^{-}, 2 \times 10^{-3} \mathrm{M}$; $\mathrm{BrO}_{3}^{-}$, $\mathrm{NO}_{3}^{-}$and $\mathrm{ClO}_{3}^{-}, 2 \times 10^{-5} \mathrm{M}$; (b) concentrations: 2 times of (a); (c) concentrations: 3 times of (a); (d) concentrations: 4 times of (a); (e) concentrations: 5 times of (a). Column, Zipax SAX (i.d. $4 \mathrm{~mm} \times 300 \mathrm{~mm}$ ); flow rate, $1.0 \mathrm{ml} / \mathrm{min}$; eluent, $1 \times 10^{-3} \mathrm{M} \mathrm{Na}_{2} \mathrm{SO}_{4}-1 \times 10^{-5} \mathrm{M} \mathrm{NaNO}_{3}$. Peak: $1, \mathrm{IO}_{3}^{-}$; $2, \mathrm{BrO}_{3}^{-} ; 3, \mathrm{NO}_{3}^{-} ; 4, \mathrm{ClO}_{3}^{-}$.

the concentrations, according to the Eq. (12), by the computer calculation (Nippon Electric Co., 9801):

$$
C=\exp \left[\left(E-E_{0}\right) / S\right.
$$

where $E_{0}, E$ and $S$ represents the base line potential, an observed potential and a Nernstian slope value, respectively. The presentation of chromatogram by a concentration unit, at least, has an apparent advantage of a small and short tailing, compared to the direct presentation by the electrode potential.

\section{References}

1. A. Jyo, Doctoral Dissertation (Doctor of Engineering), Kyushu University (1980).

2. A. Jyo, K. Mori and N. Ishibashi, Bull. Chem. Soc. Jpn., 56, 3507 (1983).

3. M. C. Franks and D. L. Pullen, Analyst [London], 99, 503 (1974).

4. K. Suzuki, H. Ariga, H. Ishiwada, T. Oshima, H. Inoue and T. Suzuki, Bunseki Kagaku, 32, 585 (1983).

5. N. Ishibashi and A. Jyo, Asahi Garasu Kogyo Gijutsu Shoreikai Kenkyu Hokoku, 33, 47 (1978).

6. C. R. Loscombe and G. B. Cox, J. Chromatogr., 166, 403 (1978).

7. P. W. Alexander, P. R. Haddad, G. K. C. Low and C. Maitra, J. Chromatogr., 209, 29 (1981).

8. T. Deguchi, T. Kuma and H. Nagai, J. Chromatogr., 152, 349 (1974).

9. F. A. Schultz and D. E. Mathis, Anal. Chem., 14, 2253 
(1974).

10. L. Campanella, G. De Angelis, T. Ferri and D. Gozzi, Analyst [London], 102, 723 (1980).

11. Dorsey, Diss. Abstr. Int. B, 40, 1672 (1980).

12. T. Imato, A. Jyo and N. Ishibashi, Anal. Chem., 52, 1893 (1980).

13. A. Jyo, T. Imato, H. Kohno and N. Ishibashi, Bull. Chem. Soc. Jpn., 56, 3177 (1983).
14. T. Imato, H. Ogawa, S. Morooka and Y. Kato, J. Membrane Sci., 13, 53 (1983).

15. A. Jyo, M. Torikai and N. Ishibashi, Bull. Chem. Soc. Jpn., 47, 2862 (1974).

16. C. F. Allen and J. W. Gates, Jr., Org. Systh. Collective Volume 3, p. 140 (1976).

(Received March 30, 1987)

(Accepted May 15, 1987) 